\title{
Update on intravitreal anti-tumor necrosis factor alpha therapies for ocular disorders
}

\author{
Isabel Pascual-Camps ${ }^{1}$, Pablo Hernández-Martínez ${ }^{1}$, Laura Monje-Fernández² ${ }^{2}$ Rosa Dolz-Marco ${ }^{\text {* }}$, \\ Roberto Gallego-Pinazo', Lihteh $\mathrm{Wu}^{3}$, J Fernando Arévalo ${ }^{4,5}$ and Manuel Díaz-Llopis ${ }^{6}$
}

\begin{abstract}
Tumor necrosis factor alpha (TNF-a) is an important pro-inflammatory cytokine associated with a variety of ocular diseases. The currently available TNF-a inhibitors are etanercept, infliximab, adalimumab, golimumab, and certolizumab. Experimental and clinical studies on the intravitreal use of these agents have been reported with etanercept, infliximab, and adalimumab: etanercept has shown limited efficacy in scarce reports; infliximab has been associated with local safety concerns but appears to benefit certain cases; adalimumab has shown no efficacy in cases of age-related macular degeneration (AMD) or diabetic macular edema (DME), but the combination with bevacizumab may be effective in refractory cases of macular diseases. Further preclinical and clinical studies are warranted in order to be able to obtain a more robust conclusion on the use of intravitreal TNF-a inhibitors.
\end{abstract}

Keywords: Tumor necrosis factor alpha; Intravitreal injection; Ocular disorders; Adalimumab; Etanercept; Infliximab

\section{Review}

Introduction

Inflammation has been implicated as one of the pivotal mediators of retinal injury in the pathogenesis of most sight-threatening ocular diseases including uveitis, diabetic retinopathy and diabetic macular edema (DME), and atrophic and neovascular age-related macular degeneration (AMD) [1,2]. Thus, a variety of anti-inflammatory and immunomodulatory agents have been tested as potential single or combination therapies in the management of intraocular inflammation, hyperpermeability, and neovascularization. Traditionally, corticosteroids have been the standard approach to this inflammatory pathway inhibition. However, their systemic and ocular safety profiles limit their use [3].

Tumor necrosis factor alpha (TNF- $\alpha$ ) is an important pro-inflammatory cytokine with pleiotropic functions synthesized mainly by $\mathrm{T}$ lymphocytes and macrophages and to a lesser extent by neutrophils and mast cells [4]. It plays a major role in the regulation of immune cells, inhibition of tumorigenesis, and inhibition of viral replication [5-8].

\footnotetext{
* Correspondence: rosadolzmarco@gmail.com

'Department of Ophthalmology, University and Polytechnic Hospital La Fe, Av. Fernando Abril Martorell, $\mathrm{n}^{\circ} 106,46026$ Valencia, Spain

Full list of author information is available at the end of the article
}

The currently available TNF- $\alpha$ inhibitors are etanercept, infliximab, adalimumab, golimumab, and certolizumab. Etanercept (Enbrel; Pfizer Inc; New York, NY, USA) is a TNF receptor-IgG fusion protein that mimics the inhibitory effects of naturally occurring soluble TNF receptors that is injected subcutaneously. Infliximab (Remicade; Schering-Plough, Rathdrum, Ireland) is a mouse-human chimeric antibody that neutralizes the biological activity of TNF- $\alpha$ by high-affinity binding to the soluble and transmembrane forms of TNF- $\alpha$, therefore preventing the effective binding of TNF- $\alpha$ with its receptors. It is administered intravenously. Adalimumab (Humira; AbbVie Inc., North Chicago, IL, USA) is a fully human monoclonal antibody that also binds selectively all forms of TNF- $\alpha$. It is also injected subcutaneously. Golimumab (Simponi; Centocor, Horsham, PA, USA, and Schering-Plough, Rathdrum, Ireland) is a fully human monoclonal antibody against TNF- $\alpha$ that is administered via a subcutaneous injection. Certolizumab (Cimzia; UCB Pharma, Brussels, Belgium) is a monoclonal antibody that combines the Fab fragment of the TNF antibody with polyethylene glycol that is delivered subcutaneously. Table 1 summarizes the main features of these molecules.

Reported risks of the systemic administration (intravenous or subcutaneous) of TNF- $\alpha$ inhibitors include fatal blood disorders, secondary infections, and reactivation of

\section{实 Springer}


Table 1 Summary of the main features of the currently available tumor necrosis factor alpha inhibitors

\begin{tabular}{ccccc}
\hline Generic name (brand name) & Molecular weight (kDa) & Mechanism of action & Route of administration & Half-life (days) \\
\hline Etanercept (Enbrel) & 150 & TNF soluble decoy receptor & Subcutaneous injection & 4 to 6 \\
Infliximab (Remicade) & 149 & Anti-TNF monoclonal antibody & Intravenous infusion & 8 to 10 \\
Adalimumab (Humira) & 148 & Anti-TNF monoclonal antibody & Subcutaneous injection & 14 \\
Golimumab (Simponi) & 150 to 151 & Anti-TNF monoclonal antibody & Subcutaneous infusion & 14 \\
Certolizumab (Cimzia) & 91 & Pegylated anti-TNF monoclonal antibody & Subcutaneous injection & 14 \\
\hline
\end{tabular}

$\mathrm{kDa}$, kilodalton; TNF, tumor necrosis factor.

latent infections, tumorigenesis, drug-induced lupus, or demyelinating central nervous system disorders among others. These potentially severe adverse events led to the investigation by ophthalmologists of alternative administration routes minimizing these risks but preserving the efficacy of the drugs. The possibility of performing intravitreal injection of TNF- $\alpha$ inhibitors could fulfill both needs [9]. However, no well-designated trials have been conducted to date [9-11], and the use of the intravitreal route of administration of TNF- $\alpha$ inhibitors has not been generalized.

The purposes of the present review are to analyze the current published evidence with regard to intravitreal injection of TNF- $\alpha$ inhibitors and to summarize the outcomes with this novel therapeutic approach.

\section{Methods}

A systematic review of all the peer-reviewed articles indexed in PubMed was performed. A comprehensive search of the literature was conducted using the online biomedical search engine PubMed. Search terms included the following: intravitreal, etanercept, infliximab, adalimumab, golimumab, certolizumab, tumor necrosis factor inhibitors. No publication date limit was applied, thus including all the available reports. Preclinical experimental models, clinical case reports, pilot studies, and case series were reviewed independently for the intravitreal use of etanercept, infliximab, and adalimumab. Relevant articles cited in papers retrieved from PubMed were also reviewed. No preclinical or clinical experience with intraocular administration of golimumab or certolizumab was found.

\section{Intravitreal experience with etanercept}

Experimental animal models showed that intravitreal injections of etanercept up to $2.5 \mathrm{mg}$ may be well tolerated without significant toxic effects on the retina $[12,13]$.

Clinical experience has been limited to a small pilot study that included seven patients with refractory DME [14]. Following two intravitreal injections of $2.5 \mathrm{mg}$ ( 0 and $1 \mathrm{~mL}$ ) of etanercept with a 2-week interval, no adverse event was registered, obtaining no significant improvement in 3 months after initiation of this treatment [14]. There is no scientific background that may reinforce the use of intravitreal injections of etanercept for the management of ocular diseases.

\section{Intravitreal experience with infliximab}

Experimental animal models showed that intravitreal injections of infliximab were tolerated up to $2.0 \mathrm{mg}$. However, doses higher than $3.3 \mathrm{mg}$ may be potentially toxic to the retina [15-20]. Also, Regatieri et al. showed in a laser-induced choroidal neovascularization model that intravitreal infliximab when injected at doses of 10 to $40 \mu \mathrm{g}$ has an anti-angiogenic effect, whereas higher doses $(320 \mu \mathrm{g})$ showed pro-angiogenic effects [21]. More recently, Yuksel et al. evidenced in a rabbit model of experimental endotoxin-induced uveitis that intravenous administration of infliximab was more effective than the intravitreal route in an acute period [22].

Beer et al. suggested that infliximab may be suitable for compounding and could be a cost-effective intravitreal medication for use in clinical practice [23]. A summary of the clinical experience reported is provided in Table 2.

Theodossiadis and colleagues treated three patients with exudative AMD unresponsive to ranibizumab with two injections of $2 \mathrm{mg}$ of infliximab given 2 months apart [24]. They reported visual improvement in all three cases $(20 / 200$ to $20 / 40 ; 20 / 200$ to $20 / 70$; and $20 / 100$ to 20/30) with no safety concerns. In contrast, Giganti et al. reported that intravitreal infliximab at a dose of $0.5 \mathrm{mg}$ in two eyes of DME and in two cases of neovascular AMD was associated with anatomic, electroretinographic, and microperimetric worsening, and three of these cases developed intraocular inflammation [25]. Arias et al. conducted a prospective interventional trial of four eyes with exudative AMD refractory to anti-vascular endothelial growth factor (VEGF) agents. They reported that intravitreal infliximab at a dose of $2 \mathrm{mg}$ did not provide any visual or anatomic benefit. Furthermore, half of their patients developed a severe intraocular inflammatory reaction [26]. The Pan-American Collaborative Retina Study Group has published the largest series on the use of intravitreal infliximab in both DME and exudative AMD. In their series, eyes with refractory DME received a single intravitreal injection of infliximab $1.0 \mathrm{mg} / 0.05 \mathrm{~mL}$ (15 eyes) or $2.0 \mathrm{mg} / 0.10 \mathrm{~mL}$ (19 eyes). No significant anatomical or functional benefit was evidenced. In addition, $42 \%$ of eyes 
Table 2 Summary of publications regarding the use of intravitreal infliximab

\begin{tabular}{|c|c|c|c|c|}
\hline Publications & Indication & Dosing & Number of cases & Main results \\
\hline $\begin{array}{l}\text { Theodossiadis } \\
\text { et al. [17] }\end{array}$ & Neovascular AMD & $2.0 \mathrm{mg} / 0.05 \mathrm{~mL}$ & 3 & $\begin{array}{l}\text { BCVA improved from } 20 / 200 \text { to } 20 / 40 \text { after two monthly injections in } \\
\text { case } 1 \text {, from } 20 / 200 \text { to } 20 / 70 \text { after two bimonthly injections in case } 2 \text {, } \\
\text { and from } 20 / 100 \text { to } 20 / 30 \text { after two injections with a 3-month interval. }\end{array}$ \\
\hline \multirow[t]{2}{*}{ Giganti et al. [25] } & Neovascular AMD & $0.5 \mathrm{mg} / 0.05 \mathrm{~mL}$ & 2 & \multirow{2}{*}{$\begin{array}{l}\text { At week } 12, \text { BCVA had declined in three patients, and } \\
\text { electroretinography and microperimetry had a decrease in all cases. }\end{array}$} \\
\hline & DME & $0.5 \mathrm{mg} / 0.05 \mathrm{~mL}$ & 2 & \\
\hline \multirow[t]{2}{*}{ Arias et al. [26] } & Neovascular AMD & $2.0 \mathrm{mg} / 0.05 \mathrm{~mL}$ & 4 & $\begin{array}{l}\text { At } 3 \text { months after a single injection, the BCVA change was }-18,+3,+4 \text {, } \\
\text { and }-4 \text { letters. }\end{array}$ \\
\hline & & & & Two cases developed severe intraocular inflammation. \\
\hline \multirow[t]{2}{*}{ Wu et al. [27] } & DME & $1.0 \mathrm{mg} / 0.05 \mathrm{~mL}$ & 15 & $\begin{array}{c}\text { BCVA changed from } 1.49 \pm 0.58 \text { to } 1.38 \pm 0.56 \log \text { MAR at } 3 \text { months } \\
\text { in the } 1 \mathrm{mg} \text { group. }\end{array}$ \\
\hline & & $2.0 \mathrm{mg} / 0.10 \mathrm{~mL}$ & 19 & $\begin{array}{c}\text { BCVA changed from } 0.76 \pm 0.5 \text { to } 1.03 \pm 0.7 \text { logMAR at } 3 \text { months in } \\
\text { the } 2 \text { mg group, } \\
\text { and } 42 \% \text { of cases developed severe intraocular inflammation. }\end{array}$ \\
\hline \multirow[t]{3}{*}{ Wu et al. [28] } & Neovascular AMD & $1.0 \mathrm{mg} / 0.05 \mathrm{~mL}$ & 8 & $\begin{array}{c}\text { BCVA changed from } 1.04 \pm 0.2 \text { to } 1.06 \pm 0.5 \log \text { MAR at } 3 \text { months in } \\
\text { the } 1 \mathrm{mg} \text { group. }\end{array}$ \\
\hline & & $2.0 \mathrm{mg} / 0.10 \mathrm{~mL}$ & 8 & $\begin{array}{c}\text { BCVA changed from } 0.94 \pm 0.5 \text { at baseline to } 0.85 \pm 0.4 \log M A R \text { in } \\
\text { the } 2 \mathrm{mg} \text { infliximab group. }\end{array}$ \\
\hline & & & & $37.5 \%$ of eyes developed severe intraocular inflammation. \\
\hline \multirow[t]{2}{*}{ Farvardin et al. [29,30] } & NIPU & $1.5 \mathrm{mg} / 0.15 \mathrm{~mL}$ & 7 & BCVA changed from $1.37 \pm 0.4$ to $1.38 \pm 0.4 \log M A R$ at 6 months. \\
\hline & & & & Vitreous haziness changed from 2.7 to 2.6 at 6 months. \\
\hline \multirow{2}{*}{$\begin{array}{l}\text { Markomichelakis } \\
\text { et al. [31] }\end{array}$} & Behçet & $1.0 \mathrm{mg} / 0.05 \mathrm{~mL}$ & 15 & BCVA changed from 0.74 to 0.3 logMAR at 30 days. \\
\hline & & & & Intraocular inflammation decreased through day 30. \\
\hline \multirow[t]{2}{*}{ Wu et al. [32] } & PCME & $1.0 \mathrm{mg} / 0.10 \mathrm{~mL}$ & 7 & BCVA changed from $1.14 \pm 0.6$ to $0.51 \pm 0.35 \log M A R$ \\
\hline & & & & Mild intraocular inflammation was observed in one case. \\
\hline
\end{tabular}

AMD, age-related macular degeneration; DME, diabetic macular edema; NIPU, noninfectious posterior uveitis; PCME, pseudoaphakic cystoid macular edema; BCVA, best-corrected visual acuity; logMAR, logarithm of the minimal angle of resolution.

injected with $2 \mathrm{mg}$ developed a severe uveitis, and three of these eyes (37.5\%) required pars plana vitrectomy [27]. Similar results were found in 26 eyes with partially responsive neovascular AMD to intravitreal injections of VEGF inhibitors. No functional gains were seen, and in addition, $37.5 \%$ of patients developed a severe uveitis that resolved with intensive topical steroid therapy [28].

Farvardin et al. reported positive both short- and longterm (6 months) outcomes after intravitreal infliximab $1.5 \mathrm{mg} / 0.15 \mathrm{~mL}$ in ten eyes of seven patients with chronic persistent noninfectious uveitis without any ocular adverse event, showing a visual mean visual improvement from $1.37 \log$ MAR to $0.67 \log$ MAR 1 month after the injection, which was not sustained by month 6 due to recurrence of macular edema and vitreous haze $[29,30]$.

Markomichelakis et al. reported that a single intravitreal injection of infliximab $1.0 \mathrm{mg} / 0.05 \mathrm{~mL}$ controlled intraocular inflammation in 15 cases with relapsing posterior uveitis associated with Behçet's disease [31].

Wu et al. found that a single intravitreal injection of infliximab $1.0 \mathrm{mg} / 0.10 \mathrm{~mL}$ achieved excellent outcomes after 6 months, without any intraocular inflammation, in seven cases of refractory pseudophakic cystoid macular edema [32].

\section{Intravitreal experience with adalimumab}

Experimental animal models have shown that intravitreal injections of adalimumab were tolerated up to $5.0 \mathrm{mg}$ without electroretinographic or histological alterations [33]. However, doses of $10.0 \mathrm{mg}$ have been associated with early retinal toxicity and a significant decrease in the photopic wave in the electroretinographic response $[34,35]$.

The Pan-American Collaborative Retina Study Group published their clinical experience with intravitreal injections of adalimumab for patients with refractory DME and partially responsive neovascular AMD to VEGF inhibitors. Intravitreal injections of adalimumab $2.0 \mathrm{mg} /$ $0.08 \mathrm{~mL}$ did not provide any anatomical or functional benefit in five cases of DME nonresponsive to conventional therapies and four cases of neovascular AMD. No ocular side effects were reported by the authors following intravitreal injections of adalimumab [26,27].

The possible role of intravitreal adalimumab in combination with anti-angiogenic agents (bevacizumab) has also been analyzed by these authors. In their case series of seven eyes of five patients with macular edema of various etiologies including partially responsive neovascular AMD, a clinically relevant response was achieved 
after combination intravitreal treatment with adalimumab $2 \mathrm{mg} / 0.08 \mathrm{~mL}$ and bevacizumab $1.25 \mathrm{mg} / 0.05 \mathrm{~mL}$ [36].

\section{Conclusions}

Overall, the literature review of all published manuscripts regarding the use of intravitreal TNF- $\alpha$ inhibitors reveals the following conclusions: 1) intravitreal injections of etanercept may not be useful in the management of ocular diseases, 2) intravitreal injections of infliximab may potentially be related to severe intraocular inflammation, 3) intravitreal injections of infliximab do not appear to benefit cases of refractory DME or partially responsive neovascular AMD, 4) intravitreal injections of infliximab may benefit cases of persistent noninfectious posterior uveitis and refractory pseudophakic cystoid macular edema, 5) intravitreal injections of adalimumab do not appear to benefit cases of DME or neovascular AMD, 6) intravitreal combination of adalimumab and bevacizumab may be effective in the management of cases with partially responsive neovascular AMD and macular edema of various etiologies, and 7) no preclinical or clinical experience with intravitreal golimumab or certolizumab has yet been published.

It is important to emphasize that all the reviewed reports include small samples, variable endpoints and follow-up periods, and heterogeneity in the doses administered, the selection criteria, and the patient population [9-11]. The off-label intravitreal use of any drug should be cautiously considered given the potentially severe adverse events that this procedure may induce. Further preclinical and clinical studies are warranted in order to be able to obtain a more robust conclusion on the use of intravitreal TNF- $\alpha$ inhibitors.

\section{Abbreviations}

AMD: age-related macular degeneration; DME: diabetic macular edema; TNF: tumor necrosis factor; VEGF: vascular endothelial growth factor.

\section{Competing interests}

The authors declare that they have no competing interests.

\section{Authors' contributions}

All authors have made substantial contributions to the conception and design, acquisition of data, or analysis and interpretation of data; have been involved in drafting the manuscript or revising it critically for important intellectual content; have given final approval of the version to be published; and agreed to be accountable for all aspects of the work in ensuring that questions related to the accuracy or integrity of any part of the work are appropriately investigated and resolved.

\section{Acknowledgements}

We thank Maria Andreu Fenoll for her valuable help in this manuscript and Dr. M Dolores Pinazo Durán for her careful review of this manuscript.

\section{Author details}

'Department of Ophthalmology, University and Polytechnic Hospital La Fe, Av. Fernando Abril Martorell, $n^{\circ}$ 106, 46026 Valencia, Spain. ${ }^{2}$ Department of Ophthalmology, University Hospital Complex, Alto de Nava s/n, 24071 Leon, Spain. ${ }^{3}$ Instituto de Cirugía Ocular, Paseo Colón, PO BOX 3971-1000 San José, Costa Rica. ${ }^{4}$ Retina Division, Wilmer Eye Institute, Johns Hopkins University School of Medicine, 600 N Wolfe St, Baltimore, MD 21287, USA. ${ }^{5}$ Vitreoretinal Division, King Khaled Eye Specialist Hospital, Al Arubah Rd, Umm AL Hamam
AL Gharbi, Riyadh 12329, Saudi Arabia. ${ }^{6}$ Faculty of Medicine, University of Valencia, Av Blasco Ibañez, 15, 46010 Valencia, Spain.

Received: 20 May 2014 Accepted: 24 September 2014 Published online: 15 October 2014

\section{References}

1. Noma H, Mimura T, Eguchi S (2013) Association of inflammatory factors with macular edema in branch retinal vein occlusion. JAMA Ophthalmol 131:160-165

2. Augustin AJ, Kirchhof J (2009) Inflammation and the pathogenesis of age-related macular degeneration. Expert Opin Ther Targets 13:641-651

3. Wang Y, Wang VM, Chan CC (2011) The role of anti-inflammatory agents in age-related macular degeneration (AMD) treatment. Eye (Lond) 25:127-139

4. Theodossiadis PG, Markomichelakis NN, Sfikakis PP (2007) Tumor necrosis factor antagonists: preliminary evidence for an emerging approach in the treatment of ocular inflammation. Retina 27:399-413

5. Bazzoni F, Beutler B (1996) The tumor necrosis factor ligand and receptor families. N Engl J Med 334:1717-1724

6. Feldmann M, Maini RN (2001) Anti-TNF-a therapy of rheumatoid arthritis: what have we learned? Annu Rev Immunol 19:163-196

7. Sfikakis PP, Kollias G (2003) TNF biology in experimental and clinical arthritis. Curr Opin Rheumatol 15:380-386

8. Croft M (2009) The role of TNF superfamily members in T-cell function and diseases. Nat Rev Immunol 9:271-285

9. Pulido JS, Pulido JE, Michet CJ, Vile RG (2010) More questions than answers: a call for a moratorium on the use of intravitreal infliximab outside of a well-designed trial. Retina 30:1-5

10. Modorati G, Miserocchi E (2012) Intravitreal injection therapy in the treatment of noninfectious uveitis. Dev Ophthalmol 51:110-121

11. Tempest-Roe S, Joshi L, Dick AD, Taylor SR (2013) Local therapies for inflammatory eye disease in translation: past, present and future. BMC Ophthalmol 6(13):39

12. Fauser S, Kalbacher H, Alteheld N, Koizumi K, Krohne TU, Joussen AM (2004) Pharmacokinetics and safety of intravitreally delivered etanercept. Graefes Arch Clin Exp Ophthalmol 242:582-586

13. Kivilcim M, Peyman GA, Kazi AA, Dellacroce J, Ghobrial RN, Monzano R (2007) Intravitreal toxicity of high-dose etanercept. J Ocul Pharmacol Ther 23:57-62

14. Tsilimbaris MK, Panagiotoglou TD, Charisis SK, Anastasakis A, Krikonis TS, Christodoulakis E (2007) The use of intravitreal etanercept in diabetic macular oedema. Semin Ophthalmol 22:75-79

15. Olson JL, Courtney RJ, Mandava N (2007) Intravitreal infliximab and choroidal neovascularization in an animal model. Arch Ophthalmol 125:1221-1224

16. Giansanti F, Ramazzotti M, Vannozzi L, Rapizzi E, Fiore T, laccheri B, Degl' Innocenti D, Moncini D, Menchini U (2008) A pilot study on ocular safety of intravitreal infliximab in a rabbit model. Invest Ophthalmol Vis Sci 49:1151-1156

17. Theodossiadis PG, Liarakos VS, Sfikakis PP, Charonis A, Agrogiannis G, Kavantzas N, Vergados IA (2009) Intravitreal administration of the anti-TNF monoclonal antibody infliximab in the rabbit. Graefes Arch Clin Exp Ophthalmol 247:273-281

18. Hosseini H, Safaei A, Khalili MR, Nowroozizadeh B, Eghtedari M, Farvardin M, Nowroozizadeh S, Tolide-le HR (2009) Intravitreal infliximab in experimental endotoxin-induced uveitis. Eur J Ophthalmol 19:818-823

19. Melo GB, Moraes Filho MN, Rodrigues EB, Regatieri CV, Dreyfuss JL, Penha FM, Pinheiro MM, Coimbra RC, Haapalainen EF, Farah ME (2012) Toxicity and retinal penetration of infliximab in primates. Retina 32:606-612

20. Rassi AR, Rigueiro MP, Isaac DL, Dourado L, Abud MB, Freitas EC, Carneiro LB, Avila MP (2011) A safety study of retinal toxicity after serial intravitreal injections of infliximab in rabbits eyes. Arq Bras Oftalmol 74:352-356

21. Regatieri CV, Dreyfuss JL, Melo GB, Lavinsky D, Farah ME, Nader HB (2009) Dual role of intravitreous infliximab in experimental choroidal neovascularization: effect on the expression of sulfated glycosaminoglycans. Invest Ophthalmol Vis Sci 50:5487-5494

22. Yuksel E, Hasanreisoglu B, Yuksel N, Yilmaz G, Ercin U, Bilgihan A (2014) Comparison of acute effect of systemic versus intravitreal infliximab treatment in an experimental model of endotoxin-induced uveitis. J Ocul Pharmacol Ther 30:74-80

23. Beer PM, Wong SJ, Schartman JP, Kulas KE, Hartman CL, Giganti M, Falk NS (2010) Infliximab stability after reconstitution, dilution, and storage under refrigeration. Retina 30:81-84 
24. Theodossiadis PG, Liarakos VS, Sfikakis PP, Vergados IA, Theodossiadis GP (2009) Intravitreal administration of the anti-tumor necrosis factor agent infliximab for neovascular age-related macular degeneration. Am J Ophthalmol 147:825-830

25. Giganti M, Beer PM, Lemanski N, Hartman C, Schartman J, Falk N (2010) Adverse events after intravitreal infliximab (Remicade). Retina 30:71-80

26. Arias L, Caminal JM, Badia MB, Rubio MJ, Catala J, Pujol O (2010) Intravitreal infliximab in patients with macular degeneration who are nonresponders to antivascular endothelial growth factor therapy. Retina 30:1601-1608

27. Wu L, Hernandez-Bogantes E, Roca JA, Arevalo JF, Barraza K, Lasave AF (2011) Intravitreal tumor necrosis factor inhibitors in the treatment of refractory diabetic macular edema: a pilot study from the Pan-American Collaborative Retina Study Group. Retina 31:298-303

28. Wu L, Arevalo JF, Hernandez-Bogantes E, Regatieri CV, Roca JA, Farah ME (2013) Intravitreal tumor necrosis factor-alpha inhibitors for neovascular agerelated macular degeneration suboptimally responsive to antivascular endothelial growth factor agents: a pilot study from the Pan American Collaborative Retina Study Group. J Ocul Pharmacol Ther 29:366-371

29. Farvardin M, Afarid M, Mehryar M, Hosseini H (2010) Intravitreal infliximab for the treatment of sight-threatening chronic noninfectious uveitis. Retina 30:1530-1535

30. Farvardin M, Afarid M, Shahrzad S (2012) Long-term effects of intravitreal infliximab for treatment of sight-threatening chronic noninfectious uveitis. J Ocul Pharmacol Ther 28:628-631

31. Markomichelakis N, Delicha E, Masselos S, Sfikakis PP (2012) Intravitreal infliximab for sight-threatening relapsing uveitis in Behçet disease: a pilot study in 15 patients. Am J Ophthalmol 154:534-541

32. Wu L, Arevalo JF, Hernandez-Bogantes E, Roca JA (2012) Intravitreal infliximab for refractory pseudophakic cystoid macular edema: results of the Pan-American Collaborative Retina Study Group. Int Ophthalmol 32:235-243

33. Tsilimbaris M, Diakonis VF, Naoumidi I, Charisis S, Kritikos I, Chatzithanasis G, Papadaki T, Plainis S (2009) Evaluation of potential retinal toxicity of adalimumab (Humira). Graefes Arch Clin Exp Ophthalmol 247:1119-1125

34. Lichtlen P, Lam TT, Nork TM, Streit T, Urech DM (2010) Relative contribution of VEGF and TNF-alpha in the cynomolgus laser-induced CNV model: comparing the efficacy of bevacizumab, adalimumab, and ESBA105. Invest Ophthalmol Vis Sci 51:4738-4745

35. Manzano RP, Peyman GA, Carvounis PE, Damico FM, Aguiar RG, loshimoto GL, Ventura DF, Cursino ST, Takahashi W (2011) Toxicity of high-dose intravitreal adalimumab (Humira) in the rabbit. J Ocul Pharmacol Ther 27:327-331

36. Arevalo JF, Serrano MA, Wu L (2013) Combined inhibition of tumor necrosis factor (TNF) and vascular endothelial growth factor (VEGF) for the treatment of macular edema of various etiologies: a short-term pilot study. Eye (Lond) 27:569-571

\section{doi:10.1186/s12348-014-0026-8}

Cite this article as: Pascual-Camps et al:: Update on intravitreal anti-tumor necrosis factor alpha therapies for ocular disorders. Journal of Ophthalmic Inflammation and Infection 2014 4:26.

\section{Submit your manuscript to a SpringerOpen ${ }^{\circ}$ journal and benefit from:}

- Convenient online submission

- Rigorous peer review

- Immediate publication on acceptance

- Open access: articles freely available online

- High visibility within the field

- Retaining the copyright to your article

Submit your next manuscript at $\gg$ springeropen.com 